\title{
THE ROLE OF FOREIGN INVESTMENT ON ECONOMIC GROWTH OF PAKISTAN: AN EMPIRICAL ANALYSIS FOR THE PERIOD OF 1976 - 2016
}

\author{
Majid Ali*
}

\begin{abstract}
The paper aims to examine empirically the nexus between foreign direct investment, domestic investments and economic growth in Pakistan by using time series data. An OLS technique is used to analyze the relationship between FDI, Public \& Private investment, Personal remittances with gross domestic products panning from 1976-2016. For a data to be stationary, ADF test has been used and validated that all variables are stationary at level. Results of the study shows that both public and private sector investment are positively related with GDP but Public sector investment have an insignificant effect on GDP, while FDI found inversely and insignificantly correlated with GDP. Personal remittances $(P R)$ relate negatively and have a significant impact on GD. Private investment are found to be the most significant variable which can effect GDP, showing that private investment can fueled economic growth of Pakistan. Hence, the Government of Pakistan needs to formulate such a policy frame work, which focuses on private sector investment in order to enhance economic growth.
\end{abstract}

Keywords: Private investment; Public investment; FDI; GDP: Pakistan

\section{Introduction}

Economic growth studies the course of action through which the productive and fruitful capacity of an economy is improved in due course to

* PhD Scholar, Faculty of Business \& Economics, Abdul Wali Khan University Mardan, KP. 
bring about increasing levels of national output and income (Todaro, 2005). Investment can play a pivotal role in a process of investigating the economic performance of a country. According to Khan and Reinhart (1990) in their study taken a sample of twenty four developing countries for a period of 1970-1979 and found that private investment can affect economic growth significantly. Khan (1996) analyzing the twin effects of public and private business investment by using the neo-classical growth model by taking a sample size of 95 developing countries from 1970-1990, he concluded that the economy was largely driven by private sector investment. Ghani and Din (2006) using VAR approach to find the nexus between investment and economic growth for the economy of Pakistan in which they included both public and private investment. Their results indicate that public investment can effect insignificantly. AKA (2007) captured the relationship between private investment and GDP by using ECM model. They identified that private investment impact significantly.

Fatima (2012) in her study used co-integration and ECM model for the economy of Pakistan. She found that investments done in private sector correlates significantly to economic growth. The role of foreign direct investment by reviving the economy is another concern for the review of literature. Numerous studies have been taken to analyzing the relationship between foreign direct inflows and economic growth. Carkovic and Levine (2002) find the impact of FDI on GDP spanning between 1960 to 1995, by using GMM panel approach, their findings indicate that FDI can affect insignificantly. Durham (2004) examined the insignificant \& negative effect of FDI on the economic growth of developing countries. Duasa (2007) used Toda and Yamamoto (1995) no causality test, to find a nexus between FDI \& GDP for Malaysian economies and found that FDI have no impact on growth rate \& vice versa. A study of Falki (2009) finds the impact of FDI on GDP for the economy of Pakistan by using OLS approach for a period of 1980-2006. He concluded that FDI have an insignificant and negative relationship with GDP. Ray (2012) examined empirically the effect of FDI on economic growth for a period of 1990- 2011 for India. He found that foreign investment does not contribute much to India's economy.

Ali (2014) used Johansen co-integration technique spanning from 19722013 and concluded the negative impact of FDI and inflation on economic growth for economy of Pakistan. Azam and Ahmad (2014) used panel data approach to investigate the effects of Human capital and Foreign direct investment on economic growth spanning from 1992-2011 by applying Endogenous model. Their empirical result indicates that FDI can be a growth enhancing. Azam (2013) examined the growth rate of four 
developing Asian economies by utilizing time series data spanning from 1976-2012. He empirically finds the effect of workers remittances on economic growth by using OLS model and found the statistical significant relationship of personal remittances with economic growth. Azam and Gavrila (2015) uses panel data to examine empirically for 10 African countries by studying the effect of inward foreign capital flow on economic growth spanning from 1977-2013. The empirical findings suggest that foreign capital and remittances are positively related to economic growth. Azam et al., (2014) examined the seven Asian economies by studying the effects of various factors on inward FDI with economic growth from 19902012. The result of this model shows that FDI and personal remittances have a positive and significant statistical impact on economic growth of these Asian economies.

Azam (2014) uses error correction model (ECM) for the contribution of foreign aid to economic growth in Pakistan spanning from 72-2012. His empirical results found the significant \& negative effect of foreign aid on the economy of Pakistan. Rehman (2016) analyzed the nexus between FDI and economic growth by examining time series data on Pakistan by applying VECM model. His findings indicate that FDI have negative effect on economic growth.

The above discussion highlighted the pivotal role of investment in boosting economic growth of Pakistan. The paper highlights the nexus between the components of investment in a shape of foreign direct investment, public investment, private investment, personal remittances and GDP in Pakistan. The OLS regression model using E-Views Version 8.0 software is adopted to achieve this objective.

\section{Data and Methodology}

\section{Sample Design and data Description}

To determine the relationship between investment and economic growth, time series data has been used for the period of 41 years from 1976 to 2016. GDP is taken as a proxy for the economic growth. Ordinary linear regression model is used to find the effect of investment on economic growth by using E-Views 8 version software. The dependent variable is GDP and independent variables are FDI, PBI, PR and PSI. The purpose of data transformation into natural logarithms form to ensure more stability, less variability and more consistency of the data for analysis. 


\section{Model Specification}

The following model which also used by including Ali (2014), Falki (2009), Azam (2016), Bahattab et al. (2016), and Rehman et al. (2018) and written as follows:

$$
L n G G D P=\beta o+\beta_{1} L n G F D I+\beta_{2} L n G P B I+\beta_{3} L n G P R+\beta_{4} L n G P S I+\epsilon
$$

Where,

LnGGDP = Natural log of GDP

LnGFDI $=$ Natural log of Foreign direct investment

LnGPBI $=$ Natural log of Public business Investment

LnGPR = Natural log of Personal Remittances

LnGPSI $=$ Natural log of private sector investment

$\beta o=$ constant

$\beta_{1}, \beta_{2}, \beta_{3}$ and $\beta_{4}$ are the coefficients.

$\epsilon=$ Regression error term

\section{Empirical Result and Discussion}

Unit Root Test: All the variables needs to be stationary at level., Unit root estimation test at $1 \%$ and $5 \%$ level of significance has been used to check the stationarity of each variable. Table 1 results shows that the GDP, FDI, PSI, PR and PBI are stationary at level.

Table 2: OLS Results (Dependent variable is GGDP)

\begin{tabular}{|l|c|c|c|c|}
\hline Variables & Coefficients & Std. Error & t- Statistics & Prob. \\
\hline Constant & 1.190712 & 0.345753 & 3.443825 & 0.0015 \\
LnGFDI & -0.036930 & 0.065383 & -0.564821 & 0.5757 \\
LnGPBI & 0.070979 & 0.095481 & 0.743382 & 0.4621 \\
LnGPR & -0.124230 & 0.060327 & -2.059280 & 0.0468 \\
LnGPSI & 0.224982 & & 2.043744 & 0.0483 \\
\hline R-squared & & 0.222043 & \\
Adjusted R-squared & & 0.135603 & \\
S.E. of regression & & 0.471114 & \\
Sum squared residual & & 7.990150 & \\
Log likelihood & & -24.65155 & \\
\hline
\end{tabular}




\section{Regression Analysis}

Ordinary least squares method is instrumental in finding the effect of every independent variable on economic growth. The relationship between the variables in this model can be shown by Beta coefficients, when the coefficient value is positive, it means that independent variables have a positive relationship with dependent variable and vice versa.

Referring to Table 2, the estimated OLS regression equation can be written as,

$$
G D P=1.19+-0.03 G F D I+0.07 G P B I+-0.12 G P R+0.22 G P S I \ldots . .
$$

The Table- 2 results shows that Public Business investment and private sector investment have a positive relation with GDP, but PBI have insignificant effect on economic growth while FDI and PR are inversely related to a dependent variable with PR having a significant effect on GDP. The model can be interpreted as $1 \%$ increase in FDI is associated with 0 $.03 \%$ decrease in GDP and a $1 \%$ increase in Public business investment associated with $0.07 \%$ increase in GDP, while and a $1 \%$ increase in Personal remittances associated with $0.12 \%$ decrease in GDP, and a $1 \%$ increase inprivate sector investment can related with $0.22 \%$ increase in GDP.

It can be noted the relation between FDI and GDP is statistically insignificant with $\mathrm{p}$ value $>0.05$ having negative impact on GDP, and personal remittances and private sector investment having significant $\mathrm{p}$ values $<0.05$.

The empirical findings are consistent with the results recorded Ghani and Din (2006) in which they examined the nexus between public investment and economic growth for Pakistan economy by applying (VAR) approach. Their results indicates that public investment have an insignificant effect on growth. It is also in line with the studies from Afonso and Aubyn (2008) where they found the relation of Public investment insignificant to Economic growth. The results are consistent with the findings of Fatima (2012) where she found that private sector investment correlates significantly to economic growth.

While, Ghura (1997) uses an OLS technique to show a significant positive impact of private investment on GDP for Cameroon economy. While Carkovic and Levine (2002) used GMM analysis \& of the opinion that FDI does not contribute significantly to economic growth. The results are also in line with Falki (2009) where she validated that FDI has a negative and insignificant relationship with GDP by using OLS Model for the time series data from 1990- 2006. The results are also consistent with the findings of Ali 
(2014) and Rehman (2016) in which they found the negative and insignificant relationship of FDI with economic growth. The negative coefficient of FDI is also consistent with the study by Kumar and Pradhan (2002) for Pakistan. Similarly Agarwal (2004) also documented negative sign of FDI coefficient i.e. 0.288 in studying for five Asian countries including Pakistan. A study conducted by Khan (2007) in Pakistan also documented the coefficient of FDI is negative i.e. 0. 27. The empirical results also correlated with the studies of Chami et al., (2005) and Burgess and Haksar, (2005) in which they found the negative relationship of remittances with economic growth. Results of this study are according to the results found by Azam et al (2017), Khan et al. (2018), Muhammad and Khan (2018).

\section{Conclusion and Recommendations}

The current paper investigates the role of investment on economic growth in Pakistan spanning from 1976 to 2016. An OLS model has been adopted by using E-Views 8 version econometrics software to analyze the relationship between FDI, PBI, PSI, PR \&GDP. The results shows that GDP positively related to public and private sector investment. It can be seen as PBI, and PSI is positively related with dependent variable while FDI and PR are negatively related to dependent variable. However, a relation between FDI and GDP is insignificant with sig. value for $\mathrm{t}-$ test is $\mathrm{p}>0.05$ having negative impact on GDP, while Public sector investment also found have insignificant affect on GDP and personal remittances and private sector investment having significant $\mathrm{p}$ values $<0.05$.

In a nutshell, it is found that the independent variables that is private and public investment are positively related to the dependent variable, but Public investment has insignificant effect on GDP, while FDI and personal remittances are negatively related to dependent variable. FDI has an insignificant effect on GDP while PR significantly correlated to GDP. In my study Public investment has an insignificant effect on GDP. Investment can used as an engine of growth to fuel the economy but the public sector in Pakistan has a constraints due to fiscal pressure in a shape of collection of inadequate revenues to meet its expenditures \& also because deterioration of misallocation of resources towards unproductive capital expenditure. The private sector investment has a significant effect on GDP, which can fuel economic growth of Pakistan. The Government should provide a conducive environment for the stimulation of private sector investment. The results of the study indicate the insignificant and negative relation of FDI to economic growth. It can be justified by the fact that in developing countries we have 
fragile institutions which constraints the growth enhancing effects of FDI. Therefore it is recommended that Government needs to focused on improving infrastructure, developing human resources and to promote local entrepreneurship and made conditions conducive for productive investment for overall economic growth. The personal remittances can negatively and significantly correlate to GDP due to the fact that remittances usages can constraints only to consumption purposes of household rather than improving the overall growth of the economy. It is suggested that Remittances should be utilized in a better way and would be growth-led enhancing. It can also be recommended that to incorporate other variables that can potentially affect the economic growth in future analysis.

\section{References}

Ali, S. (2014). Foreign capital flows and economic growth in Pakistan. Journal of World Applied Sciences 29(2): 193-201.

Agarwal, P. (2000). Economic impact of foreign direct investment in South Asia. Working Paper, Indira Gandhi Institute of Development Research., Mumbai, India.

Afanso, A. \& Mughel E-Abyun (2008). Macroeconomic rates of return of public and private investment. Working Paper Series No. 864

Aka, B.F. (2007) Relative effects of public and private investment on Cote D'Ivoire's economic performance. Applied Econometrics and International Development, 7(1), 151-158.

Azam, M. (2016). Does governance and foreign capital inflows affect economic development in OIC countries? Journal of Economic Cooperation and Development, 37(4) 21-50.

Azam, M., Khan, A.Q., Bakhtyar, B., (2017). Surveying sources of economic growth: empirical evidence from Malaysia. Problems and Perspectives in Management, 15(4), 114-123.

Azam, M. \& Ahmad, A.M., (2015). The role of human capital and foreign direct investment in promoting economic growth". International journal of social sciences. 42(2). 98-111.

Azam, M. (2014) Foreign aid and economic growth. Journal of applied economic sciences, 2 (28). 165-180.

Azam. M. (2015). The role of migrant workers remittances on fostering economic growth. International journal of social sciences. 42(80) 690-705.

Azam, M. \& L, Gavrila (2015). Inward foreign capital flows and economic growth in African countries. Journalof applied economic sciences, 3(33), 362-371. 
Azam, M., Y. Ibrahim \& B. Bakhtyar. (2014). Foreign direct investment and economic growth in asia. Actual problems of economics. 11 (61).

Bahattab, A.S., Azam, M., Gavrila, L., and Emiruallah, C., (2016). Foreign capital inflows, institutional factors and economic growth: Evidences from Republic of Yemen. Journal of Applied Economic Sciences, 5(43), 811-816.

Burgess, R., \& Haksar, V. (2005). Migration and foreign remittances in the Philippines: IMF WP/05/111. International Monetary Fund.

Carkovic, M., \& Levine,R.(2002). Does foreign direct investment accelerate economic growth? Social Science Research Network, SSRN-id314924.

Chami, R., Fullenkamp, C., \& Jahjah, S. (2005). Are immigrant remittances flows a source of capital for development? International Staff Papers 52: $55-81$.

Duasa, J. (2007) Malaysian foreign direct investment and growth: Does stability matter? Journal of Economic Corporation, 28( 2), 83-98.

Durham, J.B. ( 2004). Absorptive capacity and the effects of foreign direct investment and equity foreign portfolio investment on economic growth. European Economic Review. 48(2): 285-306.

Fatima, G. (2012). Joint impact of investment (public and private) on the economic growth of Pakistan: (co-integration approach). International Journal of Humanities and Social Science, 2(15),171-176.

Falki. N. (2009) Impact of foreign direct investment on economic growth of Pakistan, International Review of Business Research pap. 5 (5). 110120.

Ghani, E. and Musleh-ud Din. (2006). The impact of Public investment on economic growth of Pakistan. The Pakistan Development Review. 45(1), 87-98.

Ghura, D. (1997) Private investment and endogenous growth: evidence from Cameroon. IMF Working Paper, WP/97/165.

Gujratei, D.N. Basic Econometrics. Fourth Edition, Mcgraw-Hill Higher Education Commission.

Khan, A. (2007). Foreign direct investment and economic growth. The Role of Financial Domestic Financial Sector. PIDE Working paper

Khan, A.Q., Hafeez, M.H., Saleem, N., \& Azam, M. (2018). Exploring the impact of financial development on inequality: evidence from three Asian countries. Review of Economics and Development Studies, 4(2), 334-355.

Khan, M.S. (1996) Government investment and economic growth in the developing world. The Pakistan Development Review, 35 :4 Part I, 419439 . 
Khan, M.S., \& Reinhart, C.M. (1990). Private investment and economic growth in developing countries. World Development, 18(1):19-27.

Kumar, N. \& Pradhan J. (2002). Foreign direct investment, externality and economic growth in developing countries. Research and information system. New Delhi India.

Muhammad, A. and Khan, S. (2018). Inflation and the economic growth: evidence from Five Asian Countries. Pakistan Journal of Applied Economics, 28(2), 235-252.

Rehman, N. ( 2016). FDI and Economic Growth Empirical Evidence from Pakistan. Journal Of Economic And Administrative Sciences. 32(1). 63-76.

Todaro, M.P. \& Smith S.T. (2005). Development Economics" $9^{\text {th }}$ Ed., Published Addison-Wesley (E) 2005.

Ray, S. (2012). Impact of foreign direct investment on economic growth in India: aco integration analysis. Advances in Information Technology and Management (AITM). 2(1) 187-201.

Rehman, Z, Tariq, M, \& Azam, M. (2018). The role of human capital in economic development in the selected Central Asian countries. The Dialogue, XIII(03), 235-244.

Solow, M.R. (1956) A contribution to the theory of economic growth. The Quarterly Journal of Economics. 70(1):65-94.

World Bank. (2017). Data retrieved February1, 2017, from World Development Indicators Online (WDI) database. 